\title{
Causative agents for diarrhoea in under 5 children in a tertiary care hospital MK Pervin ${ }^{1}$, ST Jhora ${ }^{2}$, S Paul ${ }^{3}$, A Naher ${ }^{4}$, D Sarkar ${ }^{5}$
}

\begin{abstract}
Background: nfectious diarrhoea is a major public health problem in developing countries like Bangladesh. Bacteria and parasites are important etiological agents for diarrhoea in infants and children.

Objectives: To isolate and identify the causative organisms of diarrhoea from diarrhoeal stools in under 5 children.

Methodology: This was an observational cross sectional study carried out at Microbiology Department of Sir Salimullah Medical College, Dhaka. A total of 217 diarrhoeal patients upto 5 years age, attending Pediatric unit of Sir Salimullah Medical College and Mitford Hospital, Dhaka and Dhaka Shishu Hospital, Dhaka during the period of July 2015 to June 2016, were enrolled in the study. For isolation of enteric bacteria, diarrhoeal stools were inoculated on Mackonkey agar media and for Campylobacter spp. diarrhoeal stools were inoculated on selective Modified Campy-BAP media and nonselective Blood agar media with membrane filter. Positive culture was confirmed by Gram stain morphology and standard biochemical tests. Oocysts of Cryptosporidium were identified by Modified Ziehl Neelsen staining and other parasites were identified by wet mount preparation.
\end{abstract}

Results: Out of 217 diarrhoeal stools bacteria were isolated from 97 (44.7\%) patients. Among 97 cases, Escherichia coli were detected in 51(52.58\%) patients; Campylobacter spp. were detected in 23(23.71\%) patients; Shigella spp. were detected in 15(15.46\%) patients and Salmonella spp. were detected in $8(8.25 \%)$ patients. Microscopic finding of diarrhoeal stools were detected by pus cells with or without RBCs in 90(70.31\%) samples. Cysts of Giardia intestinalis were found in 9(4.14\%) samples, cysts of Entamoeba histolytica in $2(0.9 \%)$ samples, eggs of Trituris trichiura in 2(0.9\%) samples and oocysts of Cryptosporidium were found in.5(2.30\%) samples.

Conclusion: Escherichia coli was the most common bacteria and Giardia intestinalis was predominant parasite causing diarrhoea in under 5 children.

Key words: Diarrhoea, Bacteria, Parasites.

\section{Introduction}

Diarrhoea is a major public health problem in developing countries. Globally 1.87 million children die annually within 5 years of age from diarrhoea, accounting for $19 \%$ of all childhood deaths. ${ }^{1}$ Diarrhoea remains the second leading cause of death under 5 years and the highest mortality occur below I year of age. ${ }^{2}$

Improvement of sanitation, nutrition, education and easy access of ORS have substantially lowered the lethality of severe diarrhoea from 4.6 million in 1982 to 2.5 million in 2003. ${ }^{3}$ In developed countries an average 3.2 episodes of diarrhea per child per year has been reported, but in developing countries the number can be as high as 12 episodes per child per year. ${ }^{4}$ Among the developing countries, $78 \%$ child mortality occurred in Africa and Southeast Asia regions. 1 In 2007, yearly estimated child death was 50,800 due to diarrhoea and Bangladesh was in 7 th position. 5

The contribution of different diarrhoeal pathogens may differ substantially between regions depending on local meteorological, geographical and socioeconomic conditions. ${ }^{6}$ A wide range of

\footnotetext{
1. Mst Khashruba Pervin M. Phil, Lecturer, Dept. of Community Medicine, KMC, Khulna. (E-mail: drsurovimicrobiology@gmail.com)

2. Sanya Tahmina Jhora M. Phil, Professor and Ex Head, Dept. of Microbiology, SSMC, Dhaka.

3. Shikha Paul FCPS, Professor and Head, Dept. of Microbiology, SSMC, Dhaka.

4. Akhtarun Naher M.Phil, Professor and Ex Head, Dept. of Microbiology, SSMC, Dhaka.

5. Dipika Sarkar M.Phil, Lecturer, Dept. of Microbiology, SSMC, Dhaka
} 
bacteria, virus and parasites causes infectious diarrhoea. ${ }^{4}$ In Bangladesh, common bacterial causes of diarrhoea in children under 5 years of age are Escherichia coli-29\% (ETEC-16.8\% \& EPEC-12.2\%), Campylobacter jejuni (17.4\%) followed by Aeromonas spp. (12.2\%), Shigella $(9.2 \%)$ and Vibrio cholerae $(9 \% .)^{7}$

Among the bacterial causes, Escherichia coli is most important agent for childhood diarrhoea in developing countries. In Bangladesh, 41-46\% acute diarrhoea is caused by Escherichia coli. ${ }^{8}$ Worldwide Campylobacter spp. is one of a major cause of acute bacterial gastroenteritis among infants and children. ${ }^{9}$ In Bangladesh isolation rate of Campylobacter within 5 years of age is $11 \%$ to $17.4 \% .{ }^{10}$ Shigellosis is endemic in Bangladesh and it causes $20 \%$ of death related to diarrhoea among children. ${ }^{5}$ The intestinal protozoan parasite Giardia intestinalis (Giardia lamblia) has recently emerged as an important cause of diarrhoea in humans. ${ }^{11}$ Cryptosporidium spp. is a leading cause of diarrhoea, particularly persistent diarrhoea, in children in developing Countries.12 This study was designed to find out diarrhoeagenic bacteria and parasites from children suffering from diarrhoea under 5 years of age.

\section{Materials and methods}

This was an observational cross sectional study. The study protocol was approved by Ethical Review Committee of Sir Salimullah Medical College and Mitford Hospital, Dhaka. The study was conducted from July, 2015 to June, 2016 in Microbiological laboratory of Sir Salimullah Medical College, Dhaka.

During this period, 217 stool samples were collected from acute diarrhoeal children upto 5 years of age in Pediatric unit of Sir Salimullah Medical College and Mitford Hospital and Dhaka Shishu Hospital, Dhaka. Stools were collected in a clean, dry, wide mouth and leak proof container and brought to the Microbiological laboratory of Sir Salimullah Medical College, Dhaka within 2 hours. Cases were children upto 5 years of age passing watery or loose stools three or more times in 24 hours with/without mucus and or blood, vomiting, fever, abdominal pain. Children on antibiotic or who completed antibiotic treatment within last 15 days were excluded.

Stools were examined microscopically in saline and iodine preparation for detection of pus cells and parasites. Modified Ziehl Neelsen staining were done for detection of oocysts of Cryptosporidium. All samples were plated on
MacConkey agar media and incubated at $37^{\circ} \mathrm{C}$ for 24 hours in aerobic condition for isolation of enteric bacteria. For isolation of Campylobacter spp. stool samples were inoculated in Selective Modified Campy-BAP media (Brucella agar base with $10 \%$ defibrinated sheep blood and 3 antimicrobials Polymixin B $2.5 \mathrm{IU} / \mathrm{ml}$, Amphotericin B $2 \mathrm{mg} /$ liter and Vancomycin 10 $\mathrm{mg} /$ liter) and Non-selective Blood agar media with membrane filter $(0.45 \mathrm{~mm})$. A cellulose triacetate membrane with $0.45 \mathrm{~mm}$ pore and $47 \mathrm{~mm}$ diameter were placed on surface of Blood agar plate before inoculation. A Pasteur pipette were used to place 8 to 10 drops of stool suspension on the surface of the membrane. The filter paper were removed after 30-60 minutes. After inoculation,. media were incubated in candle jar at $420 \mathrm{C}$ for 48 hours. Suspected colonies were identified by colony character, Gram stain and standard biochemical methods. The data of the patients were collected on a structured questionnaire. All data were compiled and analyzed using Microsoft excels (2007) and presented in table to describe it in percentage.

\section{Results}

During the study period a total of 217 stool samples were collected from under 5 diarrhoeal children. Among 217 patients, majority of the children (43.32\%) were below 12 months of age group followed by 13-24 months of age group (23.50\%) (Figure 1).

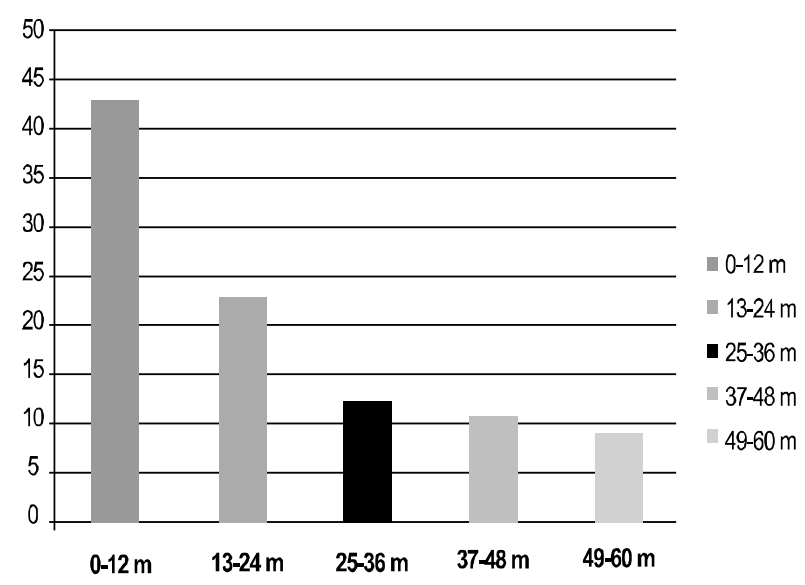

Figure 1. Different age distribution in diarrhoeal patients

Among 217 stool samples, bacteria were isolated in 97 samples $(44.7 \%)$ which were more predominant than parasites $18(8.29 \%)$ (Figure 2). 


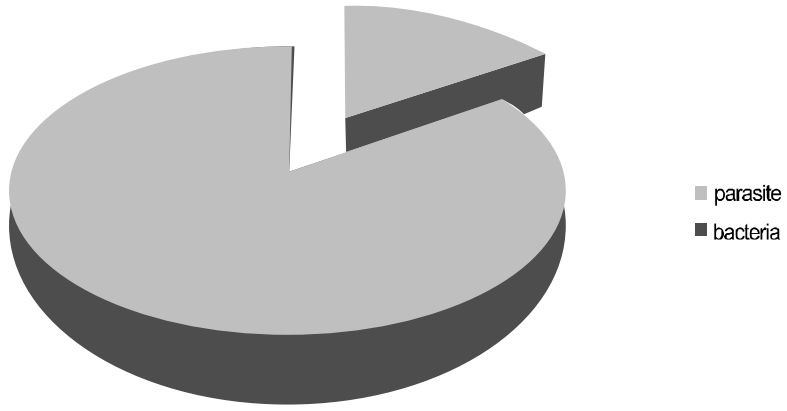

Figure 2. Distribution of causative agents of diarrhoea.

Of the 217 samples, parasites were present in $18(8.29 \%)$ stools and pus cells and/ or RBCs were present in $90(75 \%)$ stools. Among 18 parasite positive stools (Table I), cysts of Giardia intestinalis in $9(04.15 \%)$ samples, cysts of Entamoeba histolytica in $2(0.92 \%)$ samples and eggs of Trichuris trichiura were present in 2(0.92\%) samples. Modified Z-N staining detected oocysts of Cryptosporidum in $5(2.30 \%)$ samples.

\section{Table 1}

Microscopic finding of parasites in diarrhoeal stools $(n=217)$.

\begin{tabular}{lc}
\hline Microscopic finding & No. of cases (\%) \\
\hline Finding present & $18(08.29)$ \\
Wet preparation & $09(04.15)$ \\
Cysts of Giardia intestinalis & $02(00.92)$ \\
Cysts of Entamoeba histolytica & $02(00.92)$ \\
Eggs of Trichuris trichiura & \\
Modified Z N stain & $05(02.30)$ \\
Oocysts of cryptosporidium & $199(91.71)$ \\
Negative finding & $217(100)$ \\
\hline Total
\end{tabular}

Of the 217 samples, bacteria were isolated in 97(44.70\%) samples (Table II). Among the positive 97 samples, Escherichia coli were isolated in $51(52.58 \%)$ samples; Campylobacter spp. were isolated in $23(23.71 \%)$ samples; Shigella spp. were isolated in $15(15.46 \%)$ samples and Salmonella spp were isolated in $8(8.25 \%)$ samples. No bacteria were isolated in $120(55.30 \%)$ samples.

Table II

Isolation of bacteria from diarrhoeal stools by culture $(n=217)$

\begin{tabular}{lc}
\hline Name of isolated bacteria & No. of cases $(\%)$ \\
\hline Total Detected & $97(44.70)$ \\
Escherichia coli & $51(52.58)$ \\
Campylobacter spp. & $23(2371)$ \\
Shigella spp. & $15(15.46)$ \\
Salmonella spp & $08(08.25)$ \\
Not detected & $120(55.30)$ \\
\hline Total & $217(100)$ \\
\hline
\end{tabular}

\section{Discussion}

Infectious diarrhoea is one of the common causes of morbidity and mortality among infants and children in developing world. In Bangladesh, ICDDRB treats more than 1,00,000 diarrhoeal patients in a year and this number is increasing year after year.8 Knowledge about different diarrhoeal pathogens is essential for implementation of appropriate public health measure to control the diseases. ${ }^{13}$

The study included children ranging from 0 to 60 months of age. Majority of children were within 0-12 months (43.32\%) and 13-24 months (23.5\%) of age which has similarity with other study (Figure 1). ${ }^{14}$ During 0-12 months the infants have immature immune system because Protective maternal antibody begins to decline after 6 months and formula milk or food starts after 6 months.

In the study, pus cells with or without RBCs were present in $75 \%$ diarrhoeal stools. In other study of Bangladesh, 79\% pus cells and 33\% RBCs were found in diarrhoeal Stools. ${ }^{15}$ Among 217 stool samples, cysts of Giardia intestinalis was highest in $9(4.15 \%)$ samples followed by oocysts of Cryptosporidium spp. in 5(2.30\%) samples and cysts of E. histolytica and eggs of Trichuris trichiura in $2(0.92 \%)$ diarrhoeal stools. These three parasites previously reported as the most common diarrhoea causing parasites in Bangladesh. 16

Out of 217 stool samples, 97(44.7\%) bacteria were isolated in stool samples (Table-II). The aetiology of diarrhoea due to bacteria was varied due to various factors. Use of transport media, actual history of taking antibiotics before sample collection, locality, seasonality and environmental condition might affect the isolation of diarrhoeal pathogens. Among these diarrhoeal pathogens Escherichia coli was predominant and isolated in $51(23.5 \%)$ samples in this study. Roy reported $50.37 \%$ Escherichia coli from culture of diarrhoeal Stool. ${ }^{14}$ Due to poor sanitation, lack of education about personal hygiene, Escherichia coli can be transmitted from patients to patients through feco- oral route.

Campylobacter spp. were isolated in 23(10.6\%) samples of diarrhoeal stool in the current study. In Dhaka, Roy reported $13.5 \%$ Campylobacter found in acute diarrhoeal patients. ${ }^{17}$ So the rate of isolation varies from place to place where contaminated water and food of animal origin, especially improperly processed chicken acts as 
vehicle for transmission of campylobacteriosis of human. ${ }^{18}$

In this study Shigella spp. was isolated in $15(6.9 \%)$ samples from diarrhoeal stool. In Bangladesh incidence of shigellosis is higher in winter (October - January) and 9.20\% Shigella was isolated in another study. 8 But frequency of isolation of Shigella spp. $36.8 \%$ were higher in other developing countries like Nepal. ${ }^{19}$ In our study the percentage of Salmonella spp. was $8.25 \%$ whereas Nessa reported 16\% Salmonella spp. which was higher. ${ }^{20}$

\section{Conclusion}

In Bangladesh, Escherichia coli was the most common bacteria and Giardia intestinalis was common parasite causing diarrhoea in under 5 children. Therefore proper diagnosis and management of diarrhoea requires microscopy and culture facility which should be available at all level.

\section{Reference}

1. Pinto BC, Velebit L and Shibuya K. Estimating Child Mortality due to Diarrhoeal Disease in Developing Countries. Bulletin of the World Health Organization 2008; 86: 710-16.

2. Kosek M., Bern C., Guerrant R. L. The Global Burden of Diarrhoeal Disease, as Estimated from Studies Published between 1992 and 2000. Bulletin of the World Health Organization. 2003; 81:197204.

3. Black RE, Cousens $\mathrm{S}$ and Johnson HL. For the Child Health Epidemiology Reference Group of WHO and UNICEF. Global, regional and national cause of child mortality in 2008: a systematic analysis 2010; 375: 1969-1987.

4. Guerrant RL, Kisek M, Moore S, Lorntz B. Brantley R, Lima. AA. Magnitude and impact of diarrhoeal diseases. Arch Med Res 2002; 33: 351-55.

5. World Health Organization. Diarrhoeal Disease. (2009) Accessed on. 5.7.15. Available at: who.int/mediacentre/factsheetst fs330/en/ index.html.

6. Reither $\mathrm{K}$, Ignatius $\mathrm{R}$, Weitzel $\mathrm{T}$, Seidu korkor $\mathrm{A}$, Anyidoho 1, Saad E et al. Acute childhood diarrhoea in northern Ghana; epidemiological, clinical and microbiological characteristics. BMC Infect Dis 2007; 7: 104.

7. Albert MJ, Faruque ASG, Faruque SM Sack RB and Mahalanabis D. Case-Control Study of Enteropathogens Associated with Childhood Diarrhoea in Dhaka, Bangladesh. Journal of Clinical Microbiology 1999; 37: 3458-64.

8. Nessa K, Ahmed D, Islam J, Kabir FML and Hossain MA. Usefulness of a Multiplex PCR for Detection of diarrhoeagenic Escherichia coli in a diagnostic microbiology laboratory setting Bangladesh. J Med Microbiol 2007; 1: 38-42.

9. Friedman CR, Hoekstra RM Samuel M, Marcus R, Bender $\mathrm{J}$ et al. Risk Factors for Sporadic Campylobacter Infection in the United States: A Case Control Study in FoodNet Sites. Clin Infectious Dis 2004, 38: 285-96.

10. Talukder KA, Aslam M, Islam Z, Azmi IJ, Datta DK, Hossain $\mathrm{S}$ et al. Prevalence of Virulence Genes and Cytolethal Distending Toxin Production in Campylobacter jejuni Isolates from Diarrheal Patients in Bangladesh. Journal of Clinical Microbiology 2008; 46: 1485-88.

11. Suman MSH, Alam MM, Pun SB, Khairl A, Ahmed $S$ and Uchida RY. prevalence of giardia lamblia infection in children and calves in Bangladesh. Bangl. J. Vet Med 2011; 9: 177-82.

12. Latif B, Rossle NF. Cryptosporidiosis among children with diarrhoea in three Asian countries: A review. Asian Pac J Trop Biomed 2015; 5: 885-88.

13. Youssef M, Shurman A, Bougnoux ME, Rawashdeh M, Bretagne S and Strockbine N. Bacterial, viral and parasitic enteric pathogens associated with acute diarrhoea in hospitalized children from northern Jordan. FEMS Immunology \& Medical Microbiology 2000; 28: 257-63.

14. Roy S, Shamsuzzaman SM and Mamun KZ. Molecular Detection of Diarrheagenic Escherichia coli from children with acute diarrhea in Tertiary Care Hospitals of Dhaka, Bangladesh. Asian J Med Sci 2014; 5: 59-66.

15. Haq JA \& Rahman KM. Campylobacter jejuni as a cause of acute diarrhoea in children. A study at an urban hospital in Bangladesh. J Trop Med Hyg 1991; 94: 50-54.

16. Haque R, Roy S, Siddique A, Mondal U, Rahman SMM and Mondal D. Multiplex realtime PCR assay for detection of Entamoeba histolytica, Giardia intestinalis and Cryptosporidiun spp. Am. J. Trop. Med. Hy 2007; 76: 713-17.

17. Roy S, Shamsuzzaman. SM, Mamun KJ, Ahmed MJ and Haider S. Cultural isolation and PCR based assay for detection of flaA gene of Campylobacter jejuni from acute diarrhoea patients in tertiary care hospital at Dhaka, Bangladesh. British Micobiology Research Journal 2015; 10: 1-9.

18. Rizal A, Kumar A and Vidyarthi AS. Prevalence of Pathogenic Genes in Campylobacter jejuni from Poultry and Human. Internet Journal of Food Safety 2010; 12: 29-34.

19. Lama C and Sherchan JB. Enteropathogens associated diarrhoea in hospitalized patients of Children's Hospital; Kathmandu. J Nepal Heal Res Coun 2006; 5: 50-57.

20. Nessa MK, Khan MSR and Alam. Isolation, identification and characterization of Salmonella serovars from diarrhoea stool samples of human. Bangl. J. Vet. Med. 2011; 9: 85-93. 